\title{
Libraries as Trenches: Resistance, Militancy and Politics
}

\author{
Edgardo Civallero
}

Library and Information Studies Professional

Madrid, Spain

edgardocivallero@gmail.com

\begin{abstract}
This essay considers how libraries and librarians resist and mobilize by sharpening the mind and strengthening solidarity, withstanding adverse conditions and providing shelter, and allowing for new community paths to be traveled despite the neoliberal insistence that there is no alternative.

Militancy and commitment on the part of librarians are both discussed in terms of reading, literacy, identity, learning, training, and a form of leisure linked to culture. Everyday engagement in community-level activities and problem-solving by libraries goes hand-in-hand with supporting values such as justice, equality, solidarity, pluralism, freedom, equity, and respect.

Trenches are used as a metaphor for libraries because the resistance work and struggle of librarians create spaces where certain fires are kept burning to inspire people sitting around them, and where resistance, planning, building, and counteracting are all possible.
\end{abstract}

\section{Keywords}

Activism, resistance, critical librarianship, politics, militancy

\section{Introduction}

What brings us together is one 'no' and many 'yeses' of different colors.

Zapatista movement. Quoted in Ouviña (2007).

Many social and civil movements subordinate their struggles and their resistance to the will of a program, a party, a leader, or a State. Being forced to stick to a pre-established model of organization, thought, and action (or idleness), their performance is often hampered by a limited capacity to respond and come up with proposals. Such subordination weakens their position and, over time, some movements may end up being co-opted, absorbed, or just eliminated (cf. Adamovsky, 2004).

However, strong currents of independent, autonomous popular action, devoid of any partisan tinge or rhetoric, do exist; sometimes they neither have a name nor the self- 
awareness of being a "movement" or a "group." They are just anonymous citizens_part of the civil society-who agree to act in a certain way (and not in another) to defend and advance fundamental principles and rights.

While their very nature renders them barely visible or recognizable, these individuals and community organizations are still there: volunteering at soup kitchens and food banks; creating popular libraries, night schools, mutual aid associations, and cooperatives; reporting human and drug trafficking; opposing racism, sexism, and all kinds of discrimination; campaigning against the use of agrochemicals; struggling against mining projects; participating in reading groups, music bands, poetic action squads, cartoneras publishing houses, or street theatres...

These efforts of civil societies to evoke change are good examples of political action beyond institutions, even if their makers may not know it or realize it. They are examples of organizational and individual activism. Of non-violent resistance. Of militancy against oppression in all its forms. Of commitment to social justice. Of sharing a common trench in the fight against inequalities.

Everyday reality teaches us that in order to speak about all that-politics, resistance, militancy, commitment-or to put all or part of that into practice, agreeing with a particular political, ideological, philosophical, or religious creed is not mandatory or even necessary. Awareness and understanding of the situation (both in our small world and in the larger world around it) are necessary. That understanding should make clear the need for social change and be a practical guide to bringing about a fair and just society. To achieve this goal, speeches, declarations, and announcements count for less than all the direct actions unfolding daily, often unnoticed or unrecognized, in our streets, kitchens, classrooms, factories, or parks. Sometimes, a quiet decision is all that is needed; other times, a decent and resolute "no" will do.

The following paragraphs will outline some of the ways in which politics is done from this basic, daily, anonymous, and totally non-partisan perspective. Such ideas will be presented with no hint of neutrality, which is a myth used by too many to evade responsibilities, look the other way, and wash their hands. They will reflect a welldefined ideological position, committed to justice and social equality, and they will refer to a specific space: public libraries. Real libraries of all colours and all sizes, faced with urgent problems that are described by few and addressed by nobody.

Hereafter, libraries will be regarded as trenches: places for activism, critical thinking, militancy, and committed action. 


\section{Libraries as Disputed Territories}

To accept an unjust system is to cooperate with that system.

Martin Luther King. Strength to Love (1963).

In this text, "library" is understood as any space, physical or virtual, where people meet knowledge unmediated but with the help of a professional collective, the librarians. ${ }^{1}$ This knowledge may be contained in a physical medium - a book, a CD—or in a less tangible format, like the memory of a storyteller. The meeting can take place for a number of reasons, and can pursue different ends: from learning or training to pure and simple leisure.

Therefore, libraries will be considered neither as mere collections of books, nor as facilities, grounds, readers, specialized staff, and/or devices, but as the point in space and time where those elements intersect, overlap, and become interdependent.

Libraries are, were, and will be everywhere, so this conjunction of people and knowledge can happen virtually anywhere and anytime. In a suburban school, for example, inhabited by shelves loaded with handbooks and short stories. Or in a rural community, where boxes filled with magazines and novels arrive by plane or by canoe after several days of travel. Or inside a bus, a train, or a boat. Or in the canteen of any small town with books of all kinds landing on tables from backpacks and huge bags. Or in a courtyard, where an old man tells to an attentive audience stories of heroes of the past and wars of the present. Or in a downtown neighbourhood fueled by several tens of thousands of volumes carefully catalogued and classified.

The encounter between an individual —or a community, a group of people-and knowledge allows the person or the community to continue "flourishing," so to speak. Putting aside any utilitarian perspective, quantitative approach, or capitalist analysis, the ultimate force that has driven human beings throughout history has always been a continuous contact with their knowledge, their ideas, their many identities, their customs and memories, and their discoveries. And libraries-whatever their shape, whatever their size-have played and keep playing a core role in that relationship.

Libraries' main vulnerability lives within this importance. Libraries are coveted spaces that economic, institutional, political, and ideological powers seek to control as tightly as possible, whether covertly or openly. By capturing past wisdom, present knowledge, and future information, these powers are able to influence the fate of society, to manipulate its possibilities ad libitum, to close certain doors and open a few windows, to cut off change before it manifests, and to dissuade and shut down any dissent. Within capitalism, information is a most profitable asset for its owners, who gear their efforts

\footnotetext{
${ }^{1}$ For other definitions of "library" that differ from the usual ones, see Lankes (2014) and the proposals presented in such spaces and publications as In the Library with the Leadpipe or Journal of Radical Librarianship.
} 
towards controlling the production, distribution, and consumption of information, while dispensing with any obstacles standing in their way.

Libraries are therefore disputed territories, and in that strife, different strategies are deployed. The hegemonic system has sought to deprive libraries of their status as public spaces (suffocating them by shrinking budgets and staff reductions, and using capitalist logic to harness libraries' policies, missions, and functions to further business ends) and has commodified them, distorting their goals and targets, reifying their collections, and twisting their services. These actions endanger the connection between people, information, and knowledge. Many of the problems faced today by all libraries-public and otherwise-originate with the pressures introduced by and the decisions made from different spheres of power.

In response to such a devastating situation, and when so much is at stake, the most logical initial response has been, and is still, resistance.

\section{Libraries and Resistance}

Libraries are a space of resistance.

Occupy Wall Street Library (2011).

Under the battering of neoliberal capitalism, numerous public services (health, education, transportation, labour and social security, information) are being dismantled and privatized in many countries. In this scenario, the pressure upon libraries to commercialize their products and services and to achieve certain objectives and outcomes increases, and non-fulfillment of these objectives leads to drastic reductions in staff and resources. Many library systems have suffered cutbacks and closures, their budgets have been strangled, and their workers fired. Likewise, a large number of libraries (school, community, public units) are neither part of a system nor integrated into a network, and their work is hampered by a chronic lack of resources.

A high percentage of public libraries worldwide are working under increasingly worrying conditions, yet they continue to open their doors every day and to provide all the services they can as though they are part of a conscious, self-organized act of disobedience: a sort of non-violent active resistance.

In his 2013 book, British philosopher Howard Caygill recommends belief in resistance ${ }^{2}$ as one of the sole strategies for negotiating the modern world. Groups and individuals who resist become aware of their disadvantaged position in society through critical analysis of their local and historical, social, cultural, economic, and natural settings, and they refuse to obey.

Resistance and disobedience do not have to adopt a specific form. Although both terms are often associated with protests, demonstrations, or occupations of public spaces

\footnotetext{
${ }^{2}$ Resistance is an issue that has been little studied by the social sciences. See Vinthagen (2007) and García Canclini (2010) for some approaches to the subject.
} 
(and with many sensationalist headlines in media), their day-to-day actions are usually characterized by a deep and firm refusal of a particular reality that goes against their ethics and values, or is manifestly unfair, abusive, arbitrary, or illegal.

Those who resist seek viable alternatives to go on walking without bending-adhering to that verse by Spanish poet Claudio Rodriguez: "we may be defeated, but we are not tamed" ("Estamos en derrota, nunca en doma"). In general, the first step is to obtain information (a step in which libraries can and do play a very important role); the second, to join other people or groups with similar positions and/or facing the same problem(s). This way, a framework of mutual aid, support, and solidarity alliances is built. In the end, resisting is having an attitude-public or not-of defiance that is maintained over time: a goal much easier achieved by working with others.

Those resisting learn from everyday experience, improving their strategies with each mistake they make. Some sociologists and philosophers have written that resistance is a "joyful" position, although this aspect is not always present. On too many occasions, resistance is a silent and desperate act, a testimony of survival and dignity, and those who stand firm against pressures try to pass as unnoticed as possible.

Resistance acquires innumerable forms in the library arena. Examples are plentiful: digital networks sharing bibliographic resources stored in protected databases; solidarity groups gathering and transferring books and magazines from libraries that do not need them to others that do; libraries sheltered in private houses and supported by the entire community; services involving all cultural and social actors available; book repair workshops that maintain the volume of the collection; cardboard books created to increase collections; fundraising through solidary art shows, and many more. A complete inventory of experiences and practices of library resistance worldwide is beyond the scope of this article: the solutions are as diverse as the challenges that inspired them, and as varied and unique as the individuals who imagine them and put them into practice.

Resistance does exist inside libraries. And, evidently, librarians can also take their ideas and practices of resistance outside the walls of their units. ${ }^{3}$

Despite the presence of well-organized library groups, associations, and movements, most of these actions are carried out without acronyms, labels, or loudspeakers; there is, yes, a clear conscience of justice and right that pushes and motivates all these forms of dissent and disobedience. Some of the advocates of these causes and these positions are so active that one could call them true militants.

\footnotetext{
${ }^{3}$ See Iverson (1998/1999), Pateman \& Vincent (2016), and Morrone (2014) for some examples of librarians' resistance, inside and outside libraries.
} 


\section{Libraries, Militancy and Commitment}

The librarian must be the librarian militant before he can be the librarian triumphant.

Melvil Dewey. The Relation of the State to the Public Library (1889).

From an etymological point of view, the term "militant" is linked to armed conflicts. For this reason, perhaps, current use of the term generally evokes violence, or even radicalism, extremism, or terrorism. However, sensu lato the word refers to vigorous support of a cause: a "combative" way of defending ideas that does not shy away from confrontation when necessary, something perfectly achievable without any kind of violence. $^{4}$

Militancy is strongly linked to activism, which can be expressed in a number of ways. Perhaps the best known expressions of activism are street protests, which have gained greater visibility among the public and the media. However, these do not always result in the best outcomes, and are far from being the only expressions of activism.

American philosopher and activist Stephen D'Arcy (2013) remembers Martin Luther King when stating that militancy and activism are ways for an outcast society to regain its voice, make itself heard, and show its refusal to be silenced or ignored. As a matter of fact, activism and militancy represent the transition from silent opposition to a position that attempts to openly express and act out resistance, to criticize and oppose the rules of the game laid down by powers over which people have little or no democratic control, and to counterattack or step out of the box if needed. Activists and militants aim to shed light on and report systematic practices of discrimination, oppression, and domination, to confront them, to challenge them, and, whenever possible, to eliminate them. In order to do that, they resort to direct action: a practice that seeks visibility precisely because it needs to draw attention to whatever it denounces.

This approach coexists with forms of activism and militancy that are equally effective and passionate, but that could be called "micro." These are tiny gestures, small-scale changes at home, at school, in the neighbourhood, or in towns or other local levels. They are actions that trickle down day after day and require a sustained effort to counteract certain situations, to create new spaces and relations, or to modify some habits, attitudes, and behaviours.

That libraries are sites of activism - in a few cases, even undisguised militancy-is both undeniable and seldom recognized ${ }^{5}$. Libraries advocate for causes such as literacy (both traditional and informational), free access to information and knowledge, abolition of censorship, support of leisure based on one's own and others' culture, reinforcement of identities, removal of stereotypes and discrimination, and an "etcetera" too long and too rich to fit into these paragraphs.

\footnotetext{
4 The meaning of the term "militancy" has been debated for a long time now; see Nym Mayhall (2000).

${ }^{5}$ For practical examples of library activism and militancy, see Roberto \& West (2003) and Samek (2007).
} 
Resistance, activism, and militancy revolve around the idea of commitmentcommitment as awareness raising, as a result of a deepening understanding of a particular situation (social, cultural, economic, political), and as the will to respect, defend, and enforce a set of values, ideas, and beliefs. Commitment is an ideology, or a system of fundamental ideas and values that underlie and guide the thoughts and actions of a person or community.

But commitment is not just any ideology: activists and militants express a firm commitment to principles such as democracy, rule of law, justice (both social and ecological), equality, solidarity, inclusion ${ }^{6}$, pluralism, non-discrimination, freedom, equity, and respect for human rights.

By committing themselves to reality, individuals and groups become engaged, one way or another, in its transformation. In doing so, they are overcoming indifference and individualism, and they are striving for a fairer society and a more just world. Since these struggles are usually very long and, on many occasions, weary and hard, they usually are maintained from within a trench.

\section{Libraries as Trenches}

Those who do not move, do not notice their chains.

Rosa Luxemburgo.

As a war metaphor, a trench can be considered a place for survival and resistance: a small corner in the world where those who struggle for the same cause, those who share ideas and tasks, those who travel or intend to travel in the same direction, take refuge, support one another, discuss strategies, and organize themselves.

There are many spaces that can be understood as trenches, both for the work done inside them and for the experiences they shelter. Libraries are among these spaces.

Although theory and official discourses generally present libraries as politically inactive (or deactivated) places, the reality may have proven to be quite the opposite. Today, many libraries appear as places for gathering strength and knowledge, territories of mobilization, sites for intervention.

But also as trenches in which the community of users will find-or should find-a safe refuge, a reference and a lighthouse; a store of ideas and a deposit of intellectual weapons. A trench protected by the committed work of librarians, where encounters between people and knowledge will lay the ground for future action; where books and reading are defended as fundamentally valuable; where a kaleidoscope of cultures is enclosed in writing and other media, and clues for approaching different cultures are offered; in which past and present histories-those stories that turn any society into a

\footnotetext{
${ }^{6}$ About social inclusion and its relationship with LIS, see Civallero (2011).
} 
melting pot of identities-are collected; in which freedom (of expression, of access to information...), equity, and equality are protected.

In short: libraries are places from which politics can be done. Everything mentioned so far is nothing else but politics: people-librarians, readers, students, teachers-walking together, strengthening each other, and building foundations under castles-in-the-air; people organizing themselves, taking care of one another, defending their rights; people participating, deliberating, deciding.

This article has outlined the role of librarians as active militants involved in non-partisan politics from within a trench, even if such an association of words may cause some discomfort in certain sectors of the LIS community because it is an obvious, everyday reality all over the world-one that deserves to be known, divulged, and replicated.

\section{References}

Adamovsky, E. (2004). Capitalismo para principiantes. Buenos Aires: Era Naciente.

Caygill, H. (2013). On resistance: A philosophy of defiance. London: Bloomsbury.

Civallero, E. (2011). El rol de la biblioteca en la inclusión social. In XIII Jornadas de Gestión de la Información de SEDIC (Asociación Española de Documentación e Información), Madrid (Spain).

D'Arcy, S. (2013). Languages of the unheard: Why militant protest is good for democracy. Toronto: Between the Lines Press.

García Canclini, N. (2010). ¿De qué hablamos cuando hablamos de resistencia? Estudios Visuales, 7, 16-37.

Iverson, S. (1998/1999). Librarianship and resistance. Progressive Librarianship, 15, 14-19.

Lankes, D. (2014). Radical conversations: Defining a library.

Morrone, M. (Ed.). (2014). Informed agitation: Library and information skills in social justice movements and beyond. Sacramento: Library Juice Press.

Ouviña, H. (2007). Zapatismo para principiantes. Buenos Aires: Era Naciente.

Mayhall, L. E. N. (2000). Defining militancy: Radical protest, the constitutional idiom, and women's suffrage in Britain, 1908-1909. Journal of British Studies, 39 (3), 340-371. 
Pateman, J., \& Vincent, J. (2016). Public libraries and social justice. London: Routledge.

Roberto, K., \& West, J. (Eds.). (2003). Revolting librarians redux: Radical librarians speak out. Jefferson: McFarland \& Co.

Samek, T. (2007). Librarianship and human rights: A twenty-first century guide. Oxford: Chandos Publishing.

Vinthagen, S. (2007). Understanding "resistance": Exploring definitions, perspectives, forms and implications. 